Jurnal Kompetitif : Media Informasi Ekonomi Pembangunan, Manajemen dan Akuntansi

Vol. 6 No. 2, September 2020

\title{
PENGARUH CORPORATE GOVERNANCE TERHADAP MANAJEMEN LABA (Studi Pada Perusahaan Food and Baverages Yang Terdaftar di BEI \\ Pada Periode 2014-2018)
}

\author{
Pipit Rabiatun ${ }^{1)}$ \\ Irianto $^{2)}$ \\ Indah Ariffianti ${ }^{3}$ ) \\ Baiq Kisnawati ${ }^{4}$ \\ STIE AMM Mataram ${ }^{1), 2), 3), ~ \& ~ 4) ~}$ \\ 1)email: promisepipit@gmail.com \\ 2) email: irianto1301@ gmail.com \\ 3) email: indahariffianti99@gmail.com \\ 4) email: baiqkisnawati@gmail.com
}

\begin{abstract}
This study is aimed to examine the effect of corporate governance mechanisms, such as, independent board of. commissioner composition, board of commisioner size, audit committee, institutional ownership, and managerial ownership toward profit management. This research used 5 of food company and Baverages that was listed in Indonesia stock Exchange since 2014-2018. The sample of this research are selected by purposive sampling method. Analysis method of this research used multiple regression. Earnings management measured by using discretionary accrual. The result of this study showed that the result of regression as follow: $=7,365+0,631 X I+0,553 X 2+0,583$ $X 3+0,674 X 4+0,768 X 5+e$. However the result of variable: (1) Composition of independent commissioner council has the effect of significant at profit management. It was proved by $t$ value is higher than t table that was 4,291 > 2,085. (2) Standard of commissioner council has the effect of significant at profit management, it was proved by the result of $t$ value is higher than $t$ table that was 3,148 > 2,085. (3) the committee of audit has the effect of significant at profit management. It was proved by $t$ value is higher than $t$ value 3,569 > 2.085. (4) The ownership of constitutional has the effect of significant at profit management. It was proved by $t$ value is higher than table that was $4,422>2,085$. (5) The ownership of managerial at profit management. It was proved by $t$ value is higher than t table 5,618 > 2,085. (6) Composition of independent commissioner council, standard of commissioner council, the committee of audit, the ownership of constitutional, the ownership of managerial have the effect of significant at profit management. The result of calculation showed that $f$ value that is 22,861 , while $f$ table $2,74(22,861>2,74)$. It means that $f$ value is higher than $f$ table. The result of calculation of Composition of independent commissioner council, standard of commissioner council, the committee of audit, the ownership of constitutional, and the ownership of managerial showed that the value coofesien was 0,730 (73\%) and the balance 0,270 (27\%) it is described by other variable was not include in this research.
\end{abstract}

Keywords: corporate governance and earnings management. 
Jurnal Kompetitif : Media Informasi Ekonomi Pembangunan, Manajemen dan Akuntansi Vol. 6 No. 2, September 2020

\section{PENDAHULUAN}

Good Corporate Governance secara umum dikenal sebagai sistem dan struktur yang baik untuk mengelola perusahaan dengan tujuan meningkatkan nilai pemegang saham serta mengakomodasikan keberbagai pihak yang berkepentingan dengan perusahaan (stakeholder), seperti kreditur, pemasok, asosiasi bisnis, konsumen, pekerja, pemerintah dan masyarakat luas.

Good Corporate Governance bertujuan untuk menciptakan nilai tambah bagi semua pihak yang berkepentingan (stakeholder), sebagai bentuk pelaksanaan dalam mewujudkan kinerja perusahaan yang sehat. Selain penerapan Corporate Governance, faktor lain yang mempengaruhi praktik manajemen laba yaitu ukuran perusahaan. Ukuran perusahaan yang kecil dianggap lebih banyak melakukan praktik manajemen laba daripada perusahaan besar. Hal ini dikarenakan perusahaan kecil cenderung ingin memperlihatkan kondisi perusahaan yang selalu berkinerja baik agar investor menanamkan modalnya pada perusahaan tersebut. Perusahaan yang besar lebih diperhatikan oleh masyarakat sehingga mereka akan lebih berhati-hati dalam melakukan pelaporan keuangan, sehingga berdampak perusahaan tersebut melaporkan kondisinya lebih (Efendi,2005). ${ }^{1}$

Good Corporate Governance (GCG) merupakan system yang mengatur dan mengendalikan perusahaan yang menciptakan nilai tambah untuk semua Stakeholder (Monks,2003). Ada dua konsep dalam definisi tersebut, pertama, pentingnya hak pemegang saham untuk memperoleh informasi dengan benar dan tepat pada waktunya, dan kedua, kewajiban perusahaan untuk melakukan pengungkapan secara akurat, tepat waktu transparan terhadap semua informasi kinerja perusahaan kepemilikan, dan Stakeholder.

Ada empat mekanisme Corporate Governance yang sering dipakai dalam berbagai penelitian yang mengenai Corporate Governance yang bertujuan untuk mengurangi konflik keagenan.

Pertama melalui peran monitoring oleh Dewan Komisaris. Dechow Et Al (1996) dan Beasly (1996) dalam Husnul (2017) menemukan hubungan yang signifikan antara

\footnotetext{
${ }^{1}$ Effendi, Muh. Arief. 2005 Peranan Komite Audit Dalam Meningkatkan Kinerja Perusahaan. Jurnal Akutansi Pemerintah. Vol 1 No. 1 Mei: 51-57
} 
Jurnal Kompetitif : Media Informasi Ekonomi Pembangunan, Manajemen dan Akuntansi Vol. 6 No. 2, September 2020

dewan komisaris dengan pelaporan keuangan. Mereka menemukan bahwa ukuran dan independensi dewan komisaris mempengaruhi kemampuan mereka dalam memonitoring proses pelaporan keuangan. ${ }^{2}$ Hasil Penelitian Wedari (2004), Boediono (2005), serta Nasution dan Setiawan (2007) bahwa komposisi dewan komisaris independen berpengaruh negatif terhadap manajemen laba. Sedangkan Siregar dan Utama (2005) dan Ujiyantho dan Pramuka (2007) menemukan hasil positif. Untuk ukuran dewan, Ujiyantho dan Pramuka (2007) menemukan bahwa ukuran dewan tidak berpengaruh terhadap manajemen laba, sedangkan Nasution dan Setiawan (2007) menemukan hasil yang positif.

Kedua, dengan memperbesar kepemilikan saham perusahaan oleh manajemen sehingga kepentingan pemilik atau pemegang saham akan dapat disejajarkan dengan kepentingan manajer. Hasil penelitian Wedari (2004) dan Boediono (2005), bahwa kepemilikan Manajerial berpengaruh positif terhadap Manajemen laba, tetapi Ujiyantho dan Pramuka (2007) menemukan hasil negatif.

Ketiga, Kepemilikan saham oleh investor institusional. Mediastuty dan Machfoedz (2003) dalam Ujiyantho dan Pramuka (2007) menyatakan bahwa investor institusional merupakan pihak yang dapat memonitor agen dengan kepemilikannya yang besar, sehingga motivasi manajer untuk mengatur laba menjadi berkurang. Penelitian yang dilakukan Wedari (2004) dan Boediono (2005) menyatakan bahwa kepemilikan institusional berpengaruh positif terhadap manajemen laba. Sedangkan Ujiyantho dan Pramuka (2007) mengatakan tidak berpengaruh. Struktur kepemilikan (kepemilikan manajerial kepemilikan institusional) dipercaya mampu mempengaruhi jalannya perusahaan yang akhirnya berpengaruh pada kinerja perusahaan dalam mewujudkan tujuan perusahaan dalam memaksimalkan nilai perusahaan.

\footnotetext{
${ }^{2}$ Hidayat Husnul 2017. Analisis pengaruh coporate governance terhadap manajemen laba (studi pada perusahaan food and baverages yang terdapat di BEI).

3 Wedari .2004. Analisis Pengaruh Proporsi Dewan Komisaris dan Keberadaan Komite Audit Terhadap Aktivitas Manajemen Laba. Simposium Nasional Akutansi VII. Komisi E. Hal.1-12.

4 Nasution, Marihot dan doddy Setiawan. 2007. Pengaruh corporate governance Terhadap manajemen laba di Industri Perbankan Indonesia. Simposium Nasional Akutansi X. AKPM-05.Hal.1-26

5 Boediono, Gideon SB. 2005. Kualitas Laba : Studi Pengaruh Mekanisme Corporate Governance dan Dampak Manajemen Laba Dengan Menggunakan Analisis Jalur. Simposium Nasional Akutansi VIII. KAKPM-09. Hal 172-194.
} 
Jurnal Kompetitif : Media Informasi Ekonomi Pembangunan, Manajemen dan Akuntansi Vol. 6 No. 2, September 2020

Keempat, dengan membentuk komite audit. Tujuannya untuk membantu dewan komisaris dalam memastikan efektivitas sistem pengendalian internal dan efektivitas pelaksanaan tugas auditor eksternal dan internal. Komite audit memliki peran yang sangat penting dan strategis dalam hal memelihara kredibilitas proses penyusunan laporan keuangan, seperti menjaga terciptanya sistem pengawasan perusahaan yang memadai dan melaksanakan Good Corporate Governance (GCG) (Rachmawati dan Triatmoko, 2007). Wedari (2004), Siregar dan Utama (2005), serta Nasution dan Setiawan (2007) menemukan hasil bahwa komite audit berpengaruh negatif terhadap manajemen laba.

Berdasarkan uraian latar belakang di atas, yang menjadi permasalahan dalam penelitian ini adalah:

a. Apakah komposisi dewan komisaris independen berpengaruh terhadap manajemen laba pada perusahaan Food and Baverages di BEI?

b. Apakah ukuran dewan komisaris berpengaruh terhadap manajemen laba pada perusahaan Food and Baverages di BEI?

c. Apakah komite audit berpengaruh terhadap manajemen laba pada perusahaan Food and Baverages di BEI?

d. Apakah kepemilikan institusional berpengaruh terhadap manajemen laba pada perusahaan Food and Baverages di BEI?

e. Apakah kepemilikan manajerial berpengaruh terhadap manajemen laba pada perusahaan Food and Baverages di BEI?

\section{TINJAUAN PUSTAKA}

\subsection{Komposisi Dewan Komisaris Independen}

Dewan komisaris independen harus independen dari direksi dan pemegang saham pengendali dan tidak mempunyai kepentingan yang dapat mempengaruhi kemampuannya dalam menjalankan kewajiban secara adil atas nama perushaan. Keberadaan komisaris independen diatur oleh Bursa Efek Jakarta (BEJ) melalui peraturan pencatatan Efek BEI Nomor 1-A tentang ketentuan umum Pencatatan Efek Bersifat Ekuitas di Bursa tanggal 1 juli 2000, yang menyatakan bahwa perusahaan yang tercatat di BEI harus mempunyai komisaris independen yang secara propesional sama dengan jumlah saham yang dimiliki oleh pemegang saham minoritas (bukan pemegang saham pengendali). Dengan ketentuan 
Jurnal Kompetitif : Media Informasi Ekonomi Pembangunan, Manajemen dan Akuntansi Vol. 6 No. 2, September 2020

jumlah minimal komisaris independen adalah 30\% dari jumlah seluruh anggota dewan komisaris. Syarat menjadi komisaris independen antara lain (Herwidayatmo:2000): ${ }^{3}$

a. Tidak memiliki hubungan afiliasi dengan pemegang saham pengendali perusahaan bersangkutan.

b. Tidak memiliki hubungan afiliasi dengan direktur atau komisaris lainnya perusahaan bersangkutan.

c. Tidak memiliki kedudukan rangkap pada perusahaan lainnya yang terafiliasi dengan perusahaan bersangkutan.

d. Memahami peraturan perundang-undangan dibidang pasa modal.

e. Diusulkan dan dipilih oleh pemegang saham minoritas yang bukan merupakan pemegang saham pengendali dalam RUPS.

\subsection{Ukuran Dewan Komisaris}

Dewan komisaris pemegang peranan yang sangat penting dalam perusahaan, terutama dalam pelaksanaan GCG. Dewan komisaris merupakan inti dari GCG yang ditugaskan untuk menjamin pelaksanaan strategi perusahaan, mengawasi manajemen dalam mengelola perusahaan, serta mewajibkan terlaksananya akuntabilitas. Dewan Komisaris merupakan organ yang dipercaya mengawasi kebijaksanaan direksi dalam menjalankan perusahaan serta memberikan nasihat kepada direksi.

Secara umum dewan komisaris ditugaskan dan diberi tanggung jawab atas pengawasan kualitas informasi yang tekandung dalam laporan keuangan. Hal tersebut penting mengingat adanya kepentingan dari manajemen untuk melakukan manajemen laba yang berdampak pada kurangnya kepercayaan investor. Dalam upaya mengatasi hal tersebut dewan komisaris diperbolehkan untuk memiliki akses pada informasi perusahaan. Jika dewan komisaris tidak memiliki otoritas dalam perusahaan, maka dewan direksi bertanggung jawab untuk menyampaikan informasi terkait dengan perusahaan kepada dewan komisaris (National Committee on Corporate Governance, 2001 dalam Nasution dan Setiawan, $2007 .^{4}$

\footnotetext{
${ }^{6}$ Herwidayatmo. 2000. Implementasi Good Corporate Governance Untuk Perusahaan Publik Indonesia. Usahawan. No. 10 Th XXIX Oktober: 25-32.

${ }^{7}$ Nasution, Marihot dan doddy Setiawan. 2007. Pengaruh corporate governance Terhadap manajemen laba di Industri Perbankan Indonesia. Simposium Nasional Akutansi X. AKPM-05.Hal.1-26
} 
Jurnal Kompetitif : Media Informasi Ekonomi Pembangunan, Manajemen dan Akuntansi Vol. 6 No. 2, September 2020

\subsection{Komite Audit}

Sesuai dengan Kep. 29/PM/2004, Komite audit adalah komite yang dibentuk oleh dewan komisaris untuk melakukan tugas pengawasan pengelolaan perusahaan (Nasution dan Setiawan, 2007). Komite audit merupakan komite yang menangani masalah akutansi, laporan keuangan dan penjelasannya sistem pengawasan internal serta auditor independen. Komite audit memiliki pedoman kerja tertulis yang menetapkan tugas dan tanggung jawabnya dan telah disetujui oleh dewan komisaris.

Tugas komite audit dalam membantu dewan komisaris adalah (Hamdani, 2002):

a. Laporan keungan disajikan secara wajar sesuai dengan prinsip Akuntansi yang berlaku.

b. Struktur pengendalian Internal perusahaan dilaksanakan dengan baik.

c. Pelaksanaan audit Internal maupun Eksternal dilaksanakan sesuai dengan standar audiet yang berlaku.

d. Tindaklanjut temuan hasil audiet dilaksanakan oleh Manajer.

Berdasarkan Surat Edaran dari Direksi PT. Bursa Efek Jakarta No. SE 008/BEJ/12-2001 tanggal 7 Desember 2001 perihal keanggotan Komite Audit, disebutkan bahwa (Effendi, 2005):

a. Jumlah anggota Komite Audit sekurang-kurangnya 3 (tiga) orang, termasuk ketua komite audit.

b. Anggota Komite Audit yang berasal dari komisaris hanya sebanyak 1 (satu) orang. Anggota komite audit yang berasal dari komisaris tersebut harus merupakan Komisaris Independen Perusahaan Tercatat yang sekaligis menjadi Ketua Komite Audit.

c. Anggota lainnya dari Komite Audit adalah berasal dari pihak eksternal yang independen. Yang dimaksud eksternal adalah pihak diluar perusahaan Tercatat yang bukan merupakan Komisaris, direksi dan karyawan Perusahaan Tercatat, sedangkan yang dimaksud independen adalah pihak diluar perusahaan Tercatat yang tidak memiliki hubungan usaha dan hubungan afiliasi dengan perusahaan Tercatat, Komisaris, direksi dan pemegang saham Utama perusahaan Tercatat dan 
Jurnal Kompetitif : Media Informasi Ekonomi Pembangunan, Manajemen dan Akuntansi Vol. 6 No. 2, September 2020

mampu memberikan pendapat professional secara bebas sesusi dengan etika profesionalnya, tidak memihak kepada kepentingan siapapun.

Nasution dan setiawan (2007) menemukan bahwa keberadaan komite audit mempengaruhi manajemen laba, artinya komite audit yang ada di perusahaan sebagai mekanisme Corporate Governance mampu mengurangi tindak manipulasi laba oleh manajemen. Siregar dan Bachtiar (2004) dalam Nasution dan Setiawan (2007) menemukan bahwa komite audit memiliki hubungan yang signifikan dengan akurat kelolaan perusahaan manufaktur periode 2001-2002, artinya kehadiran komite audit secara efektif menghalangi peningkatan manajemen laba di perusahaan tersebut. Tetapi hasil lain ditemukan oleh Siregar dan Utama (2005) yang menguji pengaruh keberadaan komite audit dalam perusahaan terhadap manajemen laba. Hasilnya bahwa keberadaan komite audit tidak berpengaruh terhadap manajemen laba perusahaan, artinya keberadaan komite audit tidak mampu mengurangi manajemen laba yang tejadi di perusahaan.

\subsection{Kepemilikan Institusional}

Kepemilikan institusional memiliki kemampuan untuk mengendalikan pihak Manajemen melalui proses monitoring secara efektif sehingga mengurangi tindakan Manajemen melakukan Manajemen laba. Dengan presentase saham tertentu yang dimiliki oleh institusi dapat mempengaruhi proses penyususnan laporan keuangan yang tidak menutup kemungkinan terdapat akrualisasi sesuai kepentingan pihak Manajemen (Boediono,2005). Cornett et al., (2006) Menemukan adanya bukti bahwa tindakan pengawasan yang dilakukan oleh sebuah perusahaan dan pihak investor institusional dapat mendorong Manajer untuk lebih memfokuskan perhatiannya terhadap kinerja perusahaan sehingga akan mengurangi perilaku Apportunistic atau mementingkan diri sendiri. ${ }^{5}$

\subsection{Kepemilikan Manajerial}

Dari sudut pandangnya Manajemen laba sangat ditentukan oleh motivasi Manajer perusahaan. Motivasi yang berbeda akan menghasilkan besaran Manajemen laba yang berbeda, seperti antara manajer yang juga sekaligus sebagai pemegang saham dan

\footnotetext{
${ }^{8}$ Boediono, Gideon SB. 2005. Kualitas Laba : Studi Pengaruh Mekanisme Corporate Governance dan Dampak Manajemen Laba Dengan Menggunakan Analisis Jalur. Simposium Nasional Akutansi VIII. KAKPM-09. Hal 172-194.
} 
Jurnal Kompetitif : Media Informasi Ekonomi Pembangunan, Manajemen dan Akuntansi Vol. 6 No. 2, September 2020

Manajer yang tidak sebagai pemegang saham. Dua hal tersebut akan mempengaruhi Manajemen laba, sebab kepemilikan seorang Manajer akan ikut menentukan kebijkan dan pengambilan keputusan terhadap metode Akutansi yang diterapkan pada perusahaan yang dikelola. Secara umum dapat dikatakan bahwa persentase tertentu kepemilikan saham oleh Manajemen cenderung mempengaruhi tindakan Manajemen laba (Boediono,2005).

\subsection{Manajemen Laba}

Manajemen laba menurut Scott (2003:369) adalah pemilihan kebijakan oleh manajer untuk mencapai tujuan khusus. Menurut Ardiati A dan Sanjaya (2005) dapat diartikan Manajemen laba sebagai suatu proses yang dilakukan dengan sengaja dalam batasan General Accepted Accounting Principles (GAAP) untuk mengarah pada tingkatan laba pada tingkatan laba yang dilaporkan. ${ }^{6}$

Warmadewa (2010) mengatakan bahwa "Earning Management sebagai suatu proses mengambil langkah yang disengaja dalam batas prinsip akuntansi berterima umum untuk menghasilkan tingkat Earning yang dinginkan". Sedangkan menurut Scott dalam Antonia (2008), Manajemen laba adalah tindakan yang dilakukan Manajer untuk melaporkan laba yang dapat memaksimalkan kepentingan pribadi atau perusahaan dengan menggunakan kebijakan Akuntansi. Scott juga mendefinisikan manajemen laba sebagai intervensi manajemen dalam proses menyusun pelaporan keuangan eksternal sehingga dapat menaikkan atau menurunkan laba akuntansi sesuai dengan kepentingannya.

\footnotetext{
${ }^{9}$ Scott, William R. 2003. Financial Accounting Theory. New Jersey: Prentice Hall. Inc. Chapter 11:
} Earning Management. Pp. 368-392. 
Gambar 2.1 Rerangka Konseptual

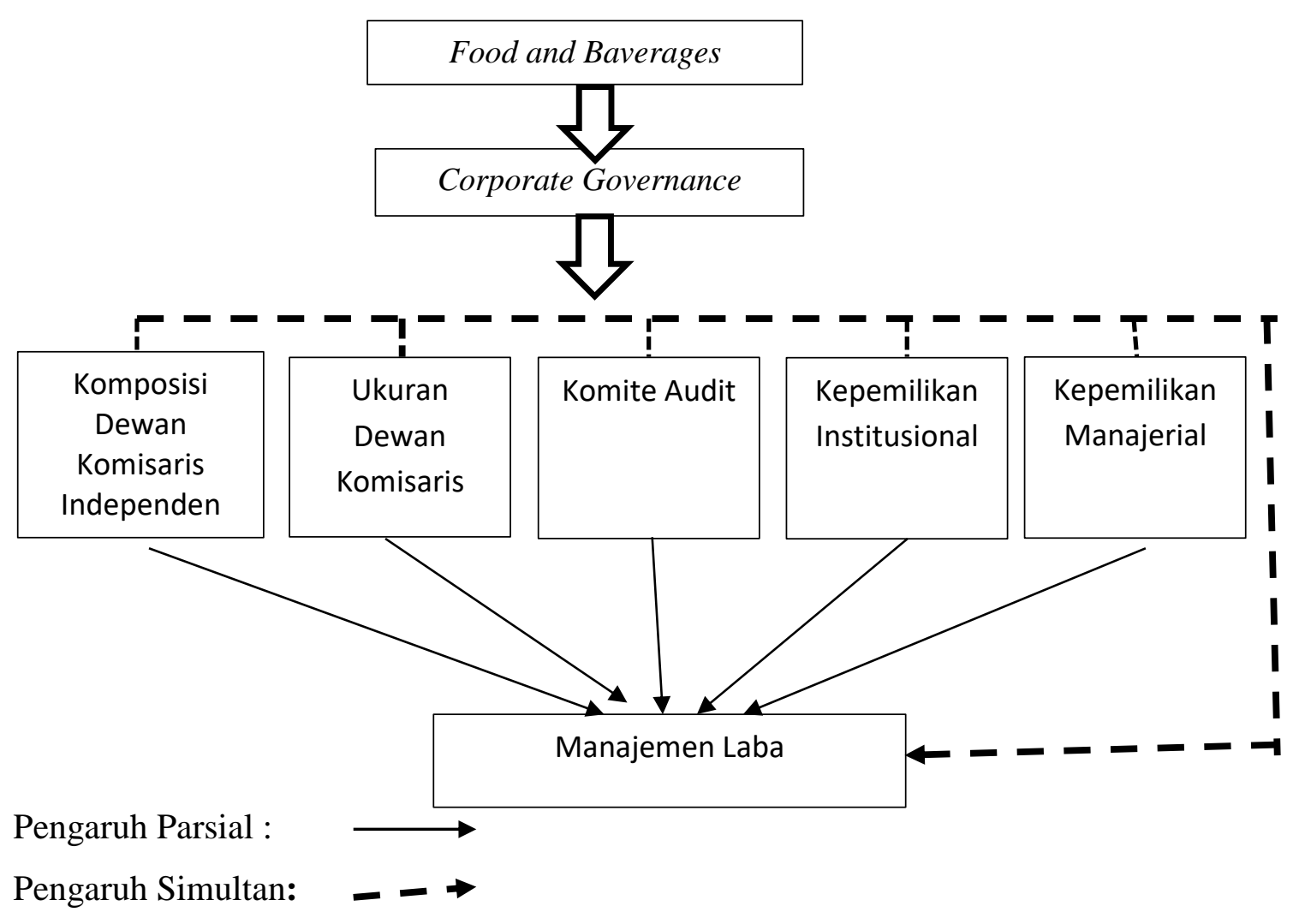

\section{METODE PENELITIAN}

Jenis penelitian yang digunakan adalah penelitian asosiatif. Penelitian asosiatif adalah penelitian yang bertujuan untuk mengetahui hubungan antara dua variabel atau lebih (Sugiyono, 2005:11). Hubungan yang digunakan dalam penelitian ini adalah hubungan kausal. Menurut Sugiyono (2005:12) hubungan kausal adalah hubungan sebab akibat dimana terdapat variabel yang mempengaruhi (independen) dan variabel yang dipengaruhi (dependen). Dalam hal ini variable independennya adalah Komposisi Dewan Komisaris Independen (X1), Ukuran Dewan Komisaris (X2), Komite Audit (X3), Kepemilikan Institusional (X4), Kepemilikan Manajerial (X5) sedangkan variable dependennya Manajemen Laba (Y). ${ }^{7}$

Jenis data yang digunakan dalam penelitian ini adalah: data kuantitatif adalah data yang berbentuk angka-angka dan dapat dianalisis secara sistematis. Data kuantitatif yang 
Jurnal Kompetitif : Media Informasi Ekonomi Pembangunan, Manajemen dan Akuntansi

Vol. 6 No. 2, September 2020

digunakan adalah data laporan keuangan auditan perusahaan Food and Baverages. Sumber data berupa data skunder dimana data yang diperoleh dalam bentuk yang sudah jadi, sudah dikumpulkan dan diolah oleh pihak lain, biasanya dalam bentuk publikasi yang digunakan sebagai pendukung data primer. Dalam hal ini berupa laporan keuangan tahunan perusahaan Food and Baverages yang terdaftar di BEI yang dapat diperoleh pada situs_www.idx.co.id dan data tambahan lainnya yang dapat diperoleh di ICMD (Indonesian Capital Market Directory)

\section{HASIL PENELITIAN DAN PEMBAHASAN}

Analisis yang digunakan untuk mengetahui besarnya pengaruh motivasi dan pengalaman kerja terhadap produktivitas kerja. Adapun hasil pengujian regresi linier berganda dengan bantuan program SPSS adalah sebagai berikut:

Coefficients $^{\mathrm{a}}$

\begin{tabular}{|c|c|c|c|c|c|c|}
\hline \multirow[t]{2}{*}{ Moc } & & \multicolumn{2}{|c|}{ Unstandardized Coefficients } & \multirow{2}{*}{$\begin{array}{c}\text { Standardized } \\
\text { Coefficients } \\
\text { Beta }\end{array}$} & \multirow[t]{2}{*}{$\mathrm{T}$} & \multirow[t]{2}{*}{ Sig. } \\
\hline & & $B$ & Std. Error & & & \\
\hline \multirow{6}{*}{1} & (Constant) & 7.365 & 2.066 & & 3.565 & .002 \\
\hline & $\begin{array}{l}\text { Komposisi Dewan Komisaris } \\
\text { Independen }\end{array}$ & .631 & .012 & .670 & 4.291 & .001 \\
\hline & Ukuran Dewan Komisaris & .553 & .021 & .432 & 3.148 & .002 \\
\hline & KomiteAudit & .583 & .023 & .523 & 3.569 & .002 \\
\hline & Kepemilikan Institusional & .674 & .042 & .701 & 4.422 & .001 \\
\hline & Kepemilikan Manajerial & .768 & .035 & .802 & 5.618 & .000 \\
\hline
\end{tabular}

a. Dependent Variable: ManajemenLaba

\section{Tabel 4.8. Hasil Uji F (Simultan) Taraf Signifikan 5\%}

\begin{tabular}{|c|c|c|c|c|c|c|}
\hline \multicolumn{7}{|c|}{ ANOVA $^{a}$} \\
\hline & & Sum of Squares & Df & Mean Square & $\mathrm{F}$ & Sig. \\
\hline \multirow{3}{*}{1} & Regression & 2.295 & 5 & \multirow{3}{*}{$\begin{array}{l}.459 \\
.533\end{array}$} & \multirow[t]{3}{*}{22.861} & \multirow[t]{3}{*}{$.000^{\mathrm{b}}$} \\
\hline & Residual & 10.127 & 19 & & & \\
\hline & Total & 12.422 & 24 & & & \\
\hline
\end{tabular}

a. Dependent Variable: ManajemenLaba

b. Predictors: (Constant), Kepemilikan Manajerial, Komposisi Dewan Komisaris Independen, KomiteAudit, Ukuran Dewan Komisaris, Kepemilikan Institusional

\section{Tabel 4.9. Hasil Koefisien Determinasi}

Model Summary

\begin{tabular}{|c|c|c|c|c|}
\hline Model & $\mathrm{R}$ & R Square & Adjusted R Square & Std. Error of the Estimate \\
\hline 1 & $.930^{\mathrm{a}}$ & .885 & .730 & .73008 \\
\hline
\end{tabular}

a. Predictors: (Constant), Kepemilikan Manajerial, Komposisi Dewan Komisaris Independen, KomiteAudit, Ukuran

Dewan Komisaris, Kepemilikan Institusional 
Jurnal Kompetitif : Media Informasi Ekonomi Pembangunan, Manajemen dan Akuntansi Vol. 6 No. 2, September 2020

Hasil pengolahan SPSS dapat ditunjukkan melalui persamaan regresi linier berganda sebagai berikut:

$\mathrm{Y}=7,365+0,631 \mathrm{X} 1+0,553 \mathrm{X} 2+0,583 \mathrm{X} 3+0,674 \mathrm{X} 4+0,768 \mathrm{X} 5+\mathrm{e}$

Persamaan tersebut menunjukkan bahwa nilai koefisien regresi untuk variable $\mathrm{X} 1$, $\mathrm{X} 2, \mathrm{X} 3, \mathrm{X} 4$, dan X5 semuanya positif ini menunjukkan bahwa jika komposisi dewan komisaris independen, ukuran dewan komisaris, komite audit, kepemilikan institusional dan kepemilikan manajerial mengalami peningkatan maka manajemen laba juga mengalami peningkatan dan jika sebaliknya variable independen tersebut mengalami penurunan maka manajemen laba juga mengalami penurunan. Dilihat dari nilai signifikansinya menunjukkan bahwa komposisi dewan komisaris independen, ukuran dewan komisaris, komite audit, kepemilikan institusional dan kepemilikan manajerial secara parsial maupun secara simultan berpengaruh terhadap manajemen laba. Koefisien determinasi menunjukkan bahwa $73 \%$ variable independen tersebut berpengaruh terhadap manajemen laba sedangkan $27 \%$ di pengaruhi oleh variable lain.

\section{KESIMPULAN DAN SARAN}

Berdasarkan hasil analisis data serta hasil pengujian hipotesis, maka dapat diperoleh kesimpulan bahwa baik secara parsial maupun secara simultan variabel komposisi dewan komisaris independen, ukuran dewan komisaris, komite audit, kepemilikan konstitusional, dan kepemilikan manajerial berpengaruh signifikan terhadap manajemen laba. Penelitian ini memiliki beberapa keterbatasan, karena hanya menggunakan sampel dari perusahaan Food and Baverages sehingga sampel dalam penelitian ini sangat terbatas. Penelitian selanjutnya diharapkan dapat menambah jumlah sampel penelitian dari berbagai kategori industri. Dengan pengambilan sampel yang berasal dari berbagai kategori industri diharapkan hasil analisis akan memiliki tingkat generalisasi yang lebih besar. Maka untuk penelitian selanjutnya perlu meneliti variable-variabel lain yang dapat menjelaskan manajemen laba seperti ukuran perusahaan dan leverage yang memiliki kemungkinan untuk berpengaruh terhadap manajemen laba.

\section{DAFTAR PUSTAKA}

Ardiati, A. dan Sanjaya. 2005. Pengaruh Manajemen Laba terhadap Return Saham Pada Perusahaan yang Diaudit oleh KAP Big 5 dan KAP non Big 5. Jurnal Riset Akuntansi Indonesia 
Jurnal Kompetitif : Media Informasi Ekonomi Pembangunan, Manajemen dan Akuntansi

Vol. 6 No. 2, September 2020

Boediono, Gideon SB. 2005. Kualitas Laba : Studi Pengaruh Mekanisme Corporate Governance dan Dampak Manajemen Laba Dengan Menggunakan Analisis Jalur. Simposium Nasional Akutansi VIII. KAKPM-09. Hal 172-194.

Effendi, Muh. Arief. 2005 Peranan Komite Audit Dalam Meningkatkan Kinerja Perusahaan. Jurnal Akutansi Pemerintah. Vol 1 No. 1 Mei: 51-57.

Herwidayatmo. 2000. Implementasi Good Corporate Governance Untuk Perusahaan Publik Indonesia. Usahawan. No. 10 Th XXIX Oktober: 25-32.

Hidayati, Siti Munfiah dan Zulaikha 2003. Analisis Perilaku Earning Management: Motivasi Minimalisasi Income Tax Simposium Nasional VI Komisi C Hal. 526538.

Hidayat Husnul 2017. Analisis pengaruh coporate governance terhadap manajemen laba (studi pada perusahaan food and baverages yang terdapat di BEI).

Nasution, Marihot dan doddy Setiawan. 2007. Pengaruh corporate governance Terhadap manajemen laba di Industri Perbankan Indonesia. Simposium Nasional Akutansi X. AKPM-05.Hal.1-26

Rachmawati, Andri dan Hanung Triatmoko. 2007. Analisis Faktor-Faktor yang mempengaruhi Kualitas Laba dan Nilai Perusahaan. Simposium Nasional AKPM16. Hal. 1-28.

Scott, William R. 2003. Financial Accounting Theory. New Jersey: Prentice Hall. Inc. Chapter 11: Earning Management. Pp. 368-392.

Sugiyono. 2005. Metode Penelitian Bisnis. Bandung : Alfabeta.

Ujiyantho, Muh. Arief dan Bambang Agus Pramuka. Pramuka 2007. Mekanisme Corporate Governance, Manajemen Laba dan Kinerja Keuangan. Simposium Nasional Akutansi X. AKPM-01 Hal. 1-26.

Warmadewa, Bhayangkara. 2010. Analisis Variabel Size Perusahaan, Pertumbuhan Penjualan, Debt to Equity Ratio (DER) dan Return on Assets (ROA) yang Mempengaruhi Praktik Perataan Laba Pada Perusahaan Jasa yang Publik di Indonesia. Tesis. Universitas Jember

Wedari .2004. Analisis Pengaruh Proporsi Dewan Komisaris dan Keberadaan Komite Audit Terhadap Aktivitas Manajemen Laba. Simposium Nasional Akutansi VII. Komisi E. Hal.1-12.

Widiatmaja, 2010. Pengaruh Mekanisme Coperative Governace Terhadap Manajemen Laba dan Konsekuensi Manajemen Laba Terhadap Kinerja Keuangan. Skripsi. Universitas Diponegoro

www.idx.co.id 